\title{
Removal of arsenate with hydrous ferric oxide coprecipitation: Effect of humic acid
}

\author{
Jingjing $\mathrm{Du}^{1}$, Chuanyong Jing ${ }^{1, *}$, Jinming Duan ${ }^{2}$, Yongli Zhang ${ }^{3, *}$, Shan $\mathrm{Hu}^{1}$ \\ 1. State Key Laboratory of Environmental Chemistry and Ecotoxicology, Research Center for Eco-Environmental Sciences, \\ Chinese Academy of Sciences, Beijing 100085, China. E-mail: jjdu@ rcees.ac.cn \\ 2. School of Environmental and Municipal Engineering, Xi'an University of Architecture and Technology, Xi'an 710055, China \\ 3. College of Architecture and Environment, Sichuan University, Chengdu 610065, China
}

\section{A R T I C L E I N F O}

\section{Article history:}

Received 01 November 2013

revised 20 December 2013

accepted 22 December 2013

\section{Keywords:}

\section{arsenate}

humic acid

HFO

adsorption

multiple spectroscopic techniques

DOI: 10.1016/S1001-0742(13)60437-4

\begin{abstract}
A B S T R A C T
Insights from the adverse effect of humic acid (HA) on arsenate removal with hydrous ferric oxide (HFO) coprecipitation can further our understanding of the fate of As(V) in water treatment process. The motivation of our study is to explore the competitive adsorption mechanisms of humic acid and $\mathrm{As}(\mathrm{V})$ on HFO on the molecular scale. Multiple complementary techniques were used including macroscopic adsorption experiments, surface enhanced Raman scattering (SERS), extended X-ray absorption fine structure (EXAFS) spectroscopy, flow-cell attenuated total reflectance Fourier transform infrared (ATR-FTIR) measurement, and charge distribution multisite complexation (CDMUSIC) modeling. The As(V) removal efficiency was reduced from over $95 \%$ to about $10 \%$ with the increasing HA concentration to 25 times of $\mathrm{As}(\mathrm{V})$ mass concentration. The SERS analysis excluded the HA-As(V) complex formation. The EXAFS results indicate that As(V) formed bidentate binuclear surface complexes in the presence of HA as evidenced by an As-Fe distance of 3.26-3.31 А. The in situ ATR-FTIR measurements show that $\mathrm{As}(\mathrm{V})$ replaces surface hydroxyl groups and forms innersphere complex. High concentrations of HA may physically block the surface sites and inhibit the $\mathrm{As}(\mathrm{V})$ access. The adsorption of $\mathrm{As}(\mathrm{V})$ and HA decreased the point of zero charge of HFO from 7.8 to 5.8 and 6.3, respectively. The CD-MUSIC model described the zeta potential curves and adsorption edges of $\mathrm{As}(\mathrm{V})$ and HA reasonably well.
\end{abstract}

\section{Introduction}

Arsenic removal using coagulation/filtration process has been demonstrated as the best available technology for large water treatment systems (US EPA, 2000). Because arsenite $(\mathrm{As}(\mathrm{III}))$ is more toxic and mobile than arsenate $(\mathrm{As}(\mathrm{V}))$, pre-oxidation of $\mathrm{As}(\mathrm{III})$ to $\mathrm{As}(\mathrm{V})$ is a conventional practice in water treatment facilities (US EPA, 2000). Ferric chloride is an effective and commonly used coagulant to remove arsenic from water, resulting in

\footnotetext{
${ }^{*}$ Corresponding author. E-mail: cyjing @rcees.ac.cn (Chuanyong Jing); zxm581212@163.com (Yongli Zhang)
}

the formation of amorphous hydrous ferric oxide (HFO) containing coprecipitated arsenic (Mercer and Tobiason, 2008).

Dissolved organic matter (DOM) is ubiquitous in surface and groundwater and its concentration ranges from 1-60 mg C/L in most fresh waters (McDonald et al., 2004). Humic substances usually comprise $50 \%-75 \%$ of DOM in aquatic system (McDonald et al., 2004), which may influence arsenic adsorption on metal oxide surfaces by several mechanisms (Grafe et al., 2001; Wang and Mulligan, 2009). Research has demonstrated that humic acid (HA) and As(V) would compete for available adsorption sites because they are both anions (Grafe et al., 2001). Predominate $\mathrm{As}(\mathrm{V})$ species, $\mathrm{H}_{2} \mathrm{AsO}_{4}^{-}$and $\mathrm{HAsO}_{4}^{2-}$, as well 
as HA, are negatively charged in the $\mathrm{pH}$ range $3-11$. As(V) adsorbs on iron oxides mainly through the formation of inner-sphere surface complexes with a predominantly bidentate configuration, along with a minor monodentate contribution, by ligand exchange with hydroxyl groups at oxide surfaces (Sherman and Randall, 2003). Ligand exchange between hydroxyl groups of DOM and iron oxide surfaces is also the predominant DOM adsorption mechanism at acidic conditions ( $\mathrm{Gu}$ et al., 1994). However, limited knowledge is available about $\mathrm{As}(\mathrm{V})$ surface complex structure on the molecular scale in the presence of HA during HFO coprecipitation at environment relevant concentrations. Insights from molecular-level mechanisms of HA-As(V)-HFO interactions can further our understanding of the fate of $\mathrm{As}(\mathrm{V})$ in water treatment process and in the environment.

Previous studies suggest that $\mathrm{As}(\mathrm{V})$ could be bound to HA through a ternary metal complexation mechanism: As(V)-metal cation-HA (Redman et al., 2002; Lin et al., 2004), and such complexes could be within colloidal size (Ritter et al., 2006). Recently, similar with As(III)-HA complex (Liu and Cai, 2012), direct association of aqueous $\mathrm{As}(\mathrm{V})$ and HA has been reported through covalent binding mechanisms (Warwick et al., 2005; Buschmann et al., 2006). Warwick et al. (2005) concluded the formation of $\mathrm{HA}-\mathrm{As}(\mathrm{V})$ complexes is favorable in the $\mathrm{pH}$ range 810 with $1500 \mathrm{mg} / \mathrm{L}$ Aldrich $\mathrm{HA}$ and $7.5 \mathrm{mg} / \mathrm{L} \mathrm{As}(\mathrm{V})$. Using an equilibrium dialysis method, Buschmann et al. (2006) suggest that about $10 \%$ of $\mathrm{As}(\mathrm{V})$ may bound to HA through phenolate functional groups in HA. However, the findings of Lin et al. (2004) show that no As(V)-DOM complexes is formed in extract of compost free of metals, whereas 30\%-50\% As( $\mathrm{V})$ is associated with DOM in the presence of metals.

The objective of this study was to investigate the effect of HA on As(V) removal with HFO coprecipitation. Surface enhanced Raman scattering (SERS) was used to study aqueous As speciation in the presence of HA. The local coordination environment of As obtained with extended X-ray absorption fine structure (EXAFS) spectroscopy and Fourier transform infrared (FT-IR) spectroscopy was employed as a molecular-level constraint in the charge distribution multisite complexation (CD-MUSIC) model. The model was used to predict As(V) adsorption behaviors including adsorption edge and zeta potential under the HA competition.

\section{Materials and methods}

\subsection{Materials}

A $1000 \mathrm{mg} / \mathrm{L} \mathrm{As}(\mathrm{V})$ stock solution was prepared by dissolving $0.4165 \mathrm{~g}$ of $\mathrm{Na}_{2} \mathrm{HAsO}_{4} \cdot 7 \mathrm{H}_{2} \mathrm{O}$ (Alfa Aesar, USA) in $100 \mathrm{~mL}$ ultrapure deionized (DI) water (18.2 M , Milli-
Q). Fe(III) stock solution containing $1000 \mathrm{mg} / \mathrm{L} \mathrm{Fe}$ and $0.1 \% \mathrm{HClO}_{4}$ was prepared using $\mathrm{FeCl}_{3}$ (Aldrich, USA) and trace metal grade $\mathrm{HClO}_{4}$ (Fisher, USA). HA was purchased from Aldrich in sodium form. The treatment of HA is essentially the same as described by Buschmann et al. (2006). In brief, $100 \mathrm{mg}$ of HA was dissolved in 1 L DI water. The $\mathrm{pH}$ was adjusted to 10 with $\mathrm{NaOH}$ and the solution was then filtered through a $0.45 \mu \mathrm{m}$ cellulose nitrate filter. The DOC concentration was determined using a Phoenix 8000 total organic carbon (TOC) analyzer (Tekmar-Dohrmann, USA). Stock solutions were stored in the refrigerator at $4{ }^{\circ} \mathrm{C}$. A background electrolyte of $0.04 \mathrm{~mol} / \mathrm{L} \mathrm{NaClO}_{4}$ prepared by dissolving HPLC grade $\mathrm{NaClO}_{4}$ (Fisher, USA) in DI water, was used in the experiments.

\subsection{Batch adsorption experiments}

Suspension samples containing $100 \mu \mathrm{g} / \mathrm{L} \mathrm{As}(\mathrm{V}), 1.0 \mathrm{mg} / \mathrm{L}$ $\mathrm{Fe}, 0-5 \mathrm{mg} / \mathrm{L} \mathrm{HA}$, and $0.04 \mathrm{~mol} / \mathrm{L} \mathrm{NaClO}_{4}$ were prepared in $100 \mathrm{~mL}$ polypropylene bottles. Three contact orders were used in the ternary adsorption system (Ko et al., 2007): (1) pre-equilibration As(V)-HA for $24 \mathrm{hr}$ before the addition of $\mathrm{Fe}$; (2) pre-equilibration $\mathrm{HA}-\mathrm{Fe}$ for $24 \mathrm{hr}$ before the addition of $\mathrm{As}(\mathrm{V})$; and (3) pre-equilibration $\mathrm{As}(\mathrm{V})$ $\mathrm{Fe}$ for $24 \mathrm{hr}$ before the addition of HA. Then, the ternary suspension was mixed for $24 \mathrm{hr}$ at $\mathrm{pH} 7.0 \pm 0.1$, and filtered through a $0.4 \mu \mathrm{m}$ membrane. The soluble As concentration in the filtrate was determined with an atomic fluorescence spectrometer (AFS, Ruiguang, China) with a detection limit of $0.6 \mu \mathrm{g} / \mathrm{L}$ (Cui et al., 2013). Triplicate adsorption experiments were performed and averaged values were reported.

Experiments were carried out to determine the As(V) adsorption edge, which is the percentage of $\mathrm{As}(\mathrm{V})$ adsorbed as a function of equilibrium $\mathrm{pH}$, in the presence and absence of HA. Suspensions containing $0.04 \mathrm{~mol} / \mathrm{L}$ $\mathrm{NaClO}_{4}, 1.0 \mathrm{mg} / \mathrm{L} \mathrm{Fe}, 100 \mu \mathrm{g} / \mathrm{L} \mathrm{As}(\mathrm{V})$, and/or $1.5 \mathrm{mg} / \mathrm{L}$ HA were prepared in a $1 \mathrm{~L}$ beaker. Then, $50 \mathrm{~mL}$ aliquots of the uniform suspensions were transferred into centrifuge tubes. The suspension $\mathrm{pH}$ was adjusted to desired levels in the range from 4 to 12 . After $24 \mathrm{hr}$ mixing, the equilibrium $\mathrm{pH}$ was measured and the suspension was filtered through a $0.45 \mu \mathrm{m}$ membrane filter for As analysis. The HA adsorption edge was determined following the same procedure with $5 \mathrm{mg} / \mathrm{L} \mathrm{HA}$ and $5 \mathrm{mg} / \mathrm{L} \mathrm{Fe}$ suspension samples.

\subsection{Electrophoretic mobility measurements}

Electrophoretic mobility (EM) was determined using a ZetaSizer Nano ZS (Malvern Instrument, UK). All EM experiments were performed under $\mathrm{N}_{2}$ atmosphere to eliminate $\mathrm{CO}_{2}$ from the system. The $\mathrm{pH}$ of the suspension containing $10 \mathrm{mg} / \mathrm{L} \mathrm{Fe}, 2 \mathrm{mg} / \mathrm{L} \mathrm{As}(\mathrm{V})$, and/or $2 \mathrm{mg} / \mathrm{L} \mathrm{HA}$ in $0.04 \mathrm{~mol} / \mathrm{L} \mathrm{NaClO}_{4}$ was adjusted to between 3 and 11 using $\mathrm{NaOH}$ and $\mathrm{HClO}_{4}$ solutions. Suspension samples were placed on a rotating shaker for $24 \mathrm{hr}$ and the final 
$\mathrm{pH}$ was measured. The reported $\zeta$ potential value was the average of three measurements.

\subsection{In situ FT-IR spectroscopic study}

FT-IR measurements were conducted using an attenuated total reflectance Fourier transform infrared (ATR-FTIR) spectrometer (Nicolet 6700, Thermo, USA) equipped with a liquid nitrogen cooled mercury-cadmium-telluride detector and an ATRMax II horizontal flow cell with $45^{\circ}$ $\mathrm{ZnSe}$ crystals (PIKE Tech, USA). The HFO film was coated on the crystal following our previous report (Yang et al., 2012). Briefly, $300 \mu \mathrm{L}$ of $1 \mathrm{~g} / \mathrm{L}$ HFO suspension were spread on the surface of the crystal and dried under a $\mathrm{N}_{2}$ stream. The crystal was gently rinsed with 0.01 $\mathrm{mol} / \mathrm{L} \mathrm{NaCl}$ before placed into the flow cell. The flow cell was connected via PEEK tubing and Shimadzu LC$3 \mathrm{~A}$ pump to $\mathrm{As}(\mathrm{V})$ and $\mathrm{HA}$ solutions at $0.3 \mathrm{~mL} / \mathrm{min}$ flow rate. The solution was flow over the HFO film and spectra were recorded over intervals for up to $8 \mathrm{hr}$. Spectra were collected using 256 scans at $4 \mathrm{~cm}^{-1}$ resolution. No baseline correction or smoothing was applied to any spectrum.

\subsection{SERS analysis}

The silver surface on a glass slide was prepared by the mirror reaction, which involves the reduction of silver nitrate by glucose. This procedure to prepare SERS substrate is described in detail elsewhere (Saito et al., 2002). Samples containing $1 \mathrm{mg} / \mathrm{L} \mathrm{As}(\mathrm{V})$ and 1,5 , and $10 \mathrm{mg} / \mathrm{L} \mathrm{HA}$, respectively, were mixed for $48 \mathrm{hr}$ at $\mathrm{pH} 7$. A $25 \mu \mathrm{L}$ sample was dipped on the SERS substrate and the SERS spectra were obtained using Nicolet Almega XR Raman spectrometer equipped with a $35 \mathrm{~mW}$ near-infrared diode laser at a wavelength of $785 \mathrm{~nm}$ for excitation (Thermo, USA). The laser beam was set in position through an Olympus BX51 research-grade microscope objective $(20 \times)$. The spectra were recorded with a resolution of $4 \mathrm{~cm}^{-1}$ using an average of five scans with $10 \mathrm{sec}$ accumulation for each scan. To test the possibility of aqueous HA-As complex formation at high $\mathrm{As}(\mathrm{V})$ concentrations, a mixture of $10 \mathrm{mg} / \mathrm{L} \mathrm{As}(\mathrm{V})$ and $\mathrm{HA}$ was mixed for 5 days at $\mathrm{pH} 7$. A solution containing $10 \mathrm{mg} / \mathrm{L} \mathrm{As}(\mathrm{V})$ and $8 \mathrm{mg} / \mathrm{L} \mathrm{Ca}$ (As:Ca molar ratio = $2: 3)$ was also prepared in the same way as a comparison. The Raman system used in high As concentration (10 $\mathrm{mg} / \mathrm{L}$ ) study was an EZRaman-I instrument from Enwave Optronics Inc. with $4 \mathrm{~cm}^{-1}$ resolution at $785 \mathrm{~nm}$ excitation.

\subsection{EXAFS analysis}

The EXAFS samples were prepared using the same experimental methods as described above for batch adsorption experiments. Suspension samples containing $0.04 \mathrm{~mol} / \mathrm{L}$ $\mathrm{NaClO}_{4}, 10 \mathrm{mg} / \mathrm{L} \mathrm{As}(\mathrm{V}), 100 \mathrm{mg} / \mathrm{L} \mathrm{Fe}$, and HA with concentrations at $0,25,100$, and $200 \mathrm{mg} / \mathrm{L}$, respectively, were mixed at $\mathrm{pH} 7$ in $1 \mathrm{~L}$ plastic bottles. After 24 $\mathrm{hr}$ mixing, the samples were filtered through a $0.45 \mu \mathrm{m}$ membrane filter. The wet paste was sealed between two layers of X-ray transparent Kapton tape, and analyzed on beamline 14W1 at Shanghai Synchrotron Radiation Facility, China.

An energy range of -200 to $1000 \mathrm{eV}$ from the K-edge of As $(11,867 \mathrm{eV})$ was used to acquire the spectra. The spectra were collected in fluorescence mode using a Lytle detector positioned at $90^{\circ}$ to the incident beam, and the sample was at a $45^{\circ}$ sample, inspected for overall quality and averaged to improve the signal/noise ratio.

The EXAFS spectra were analyzed using the Athena and Artemis program in the IFEFFIT computer package (Ravel and Newville, 2005). The standard EXAFS data process was followed as used in our previous research (Jing et al., 2012; Yu et al., 2012). Briefly, the spectra were processed by removing the background absorbance with a linear function through the pre-edge region, normalizing the atomic absorption, and extracting the EXAFS signal from the spectra. Then the data were converted from energy to photoelectron momentum ( $k$ space) and weighted by $k^{3}$ to account for the dampening of oscillations with increasing $k$. Spectra were Fourier transformed and fitted in R-space $(\AA)$ in which the coordination number $(\mathrm{CN})$, interatomic distance $(R)$, and Debye-Waller parameter $\left(\chi^{2}\right)$ were varied to give the best fit between the experimental and predicted spectra. The theoretical phase shift and amplitude functions were calculated with the $a b$ initio computer code FEFF6 using atomic clusters generated from the crystal structure of scorodite $\left(\mathrm{FeAsO}_{4} \cdot 2 \mathrm{H}_{2} \mathrm{O}\right)$. The goodness-of-fit parameters were also calculated and compared including $\chi^{2}$ and $\mathrm{R}$-factor, the relative error of the fit and data. Good fits occur for $R<0.05$.

\subsection{Surface complexation modeling}

The CD-MUSIC model with the triple plane option was used to describe As(V) and HA adsorption behaviors. The basic principles of the model have been well documented in the literature (Hiemstra and vanRiemsdijk, 1996). Constants for protonation of the surface hydroxyl groups and formation of outer-sphere complexes with background electrolytes were taken from our previous study (Jing et al., 2012) and listed in Table S1. Only singly coordinated surface group, $\mathrm{FeOH}^{-1 / 2}$, was responsible for the As(V) and HA adsorption in the CD-MUSIC modeling. The As(V) and HA surface complexation constants were optimized by fitting model-calculated values to the experimental data. The constants were varied systematically until the difference ((experimental adsorption-calculated adsorption $)^{2}$ ) between the calculated and observed values reached a minimum. The calculation was performed using the chemical equilibrium program Visual MINTEQ with the 1-pk TPM adsorption option. The $\zeta$ potential was also calculated according to our previous report (Jing et al., 2005). 


\section{Results and discussion}

\section{1 $\mathrm{As}(\mathrm{V})$ removal in the presence of $\mathrm{HA}$}

The results in Fig. 1 show concentrations of $\mathrm{As}(\mathrm{V})$ remaining in solution with three contact orders in the As(V)HA-HFO ternary system: pre-equilibration of As(V)-HA, HA-HFO, and As(V)-HFO. The initial $100 \mu \mathrm{g} / \mathrm{L} \mathrm{As(V)}$ was reduced to $4.7 \mu \mathrm{g} / \mathrm{L}$ with $1 \mathrm{mg} / \mathrm{L} \mathrm{Fe}$ in the absence of HA (Fig. 1a). When the HA concentration was increased from 0 to $0.5 \mathrm{mg} / \mathrm{L}$, average residual $\mathrm{As}(\mathrm{V})$ concentration was slightly increased from 4.7 to $6.5 \mu \mathrm{g} / \mathrm{L}$. However, the differences between these two residual $\mathrm{As}(\mathrm{V})$ concentrations were not statistically significant $(p=0.355)$. The results suggest that at 5 times of $\mathrm{As}(\mathrm{V})$ mass concentration, HA could not affect the As(V) adsorption. The finding is in agreement with a previous report that $\mathrm{As}(\mathrm{V})$ adsorption on HFO is not decreased in the presence of equal concentration of HA (Grafe et al., 2002). When the HA concentration was increased to $1 \mathrm{mg} / \mathrm{L}$ which was 10 times of initial $\mathrm{As}(\mathrm{V})$ mass concentration, the $\mathrm{As}(\mathrm{V})$ removal efficiency was decreased from approximately $95 \%$ to $90 \%$ which showed a significant difference $(p=0.049)$. In the presence of $2.5 \mathrm{mg} / \mathrm{L} \mathrm{HA}$ corresponding to 25 times of
As(V) mass concentration, only about $10 \%$ As(V) was removed. This $\mathrm{As}(\mathrm{V})$ removal efficiency was not further decreased even when the mass concentration ratio of HA to $\mathrm{As}(\mathrm{V})$ was increased to 50.

Upon pre-equilibration of HA-HFO, As(V) removal by HFO was substantially inhibited (Fig. 1b). The observed adverse effect of HA on As removal was in agreement with previous reports (Grafe et al., 2001; Redman et al., 2002), which could be attributed to the competitive adsorption of HA for available adsorption sites. When As(V) was preequilibrated with HFO, the addition of HA only extracted less than $40 \mu \mathrm{g} / \mathrm{L} \mathrm{As}(\mathrm{V})$ (Fig. 1c). With the increase of HA concentrations, the extracted $\mathrm{As}(\mathrm{V})$ was slightly reduced from 38.3 to $21.6 \mu \mathrm{g} / \mathrm{L}$ due to aggregating effect of the macromolecular HA.

\subsection{SERS study}

In order to study the possible formation of HA-As(V) aqueous complexes which could subsequently reduce the $\mathrm{As}(\mathrm{V})$ adsorption, SERS was employed as it provides a ultrasensitive chemical analysis for molecular structure of the sample. The SERS spectra shown in Fig. 2A demonstrate that a peak at $785 \mathrm{~cm}^{-1}$ was observed for
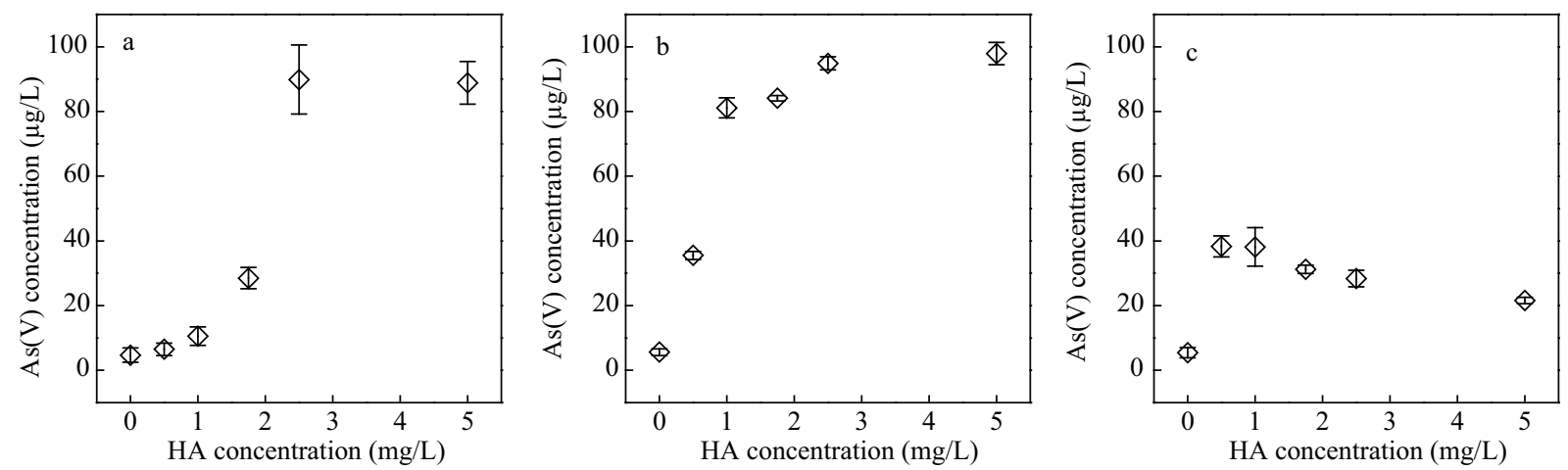

Fig. 1 Remaining As(V) concentration in the As(V)-HA-HFO ternary system with three contact orders: (a) pre-equilibration As(V)-HA for 24 hr before the addition of Fe; (b) pre-equilibration HA-HFO for $24 \mathrm{hr}$ before the addition of As(V); (c) pre-equilibration As(V)-HFO for 24 hr before the addition of HA. Fe $=1 \mathrm{mg} / \mathrm{L}$, initial As $=100 \mu \mathrm{g} / \mathrm{L}, \mathrm{I}=0.04 \mathrm{~mol} / \mathrm{L} \mathrm{NaClO} 4, \mathrm{pH}=7$. The error bar shows the standard deviation of triplicate samples.
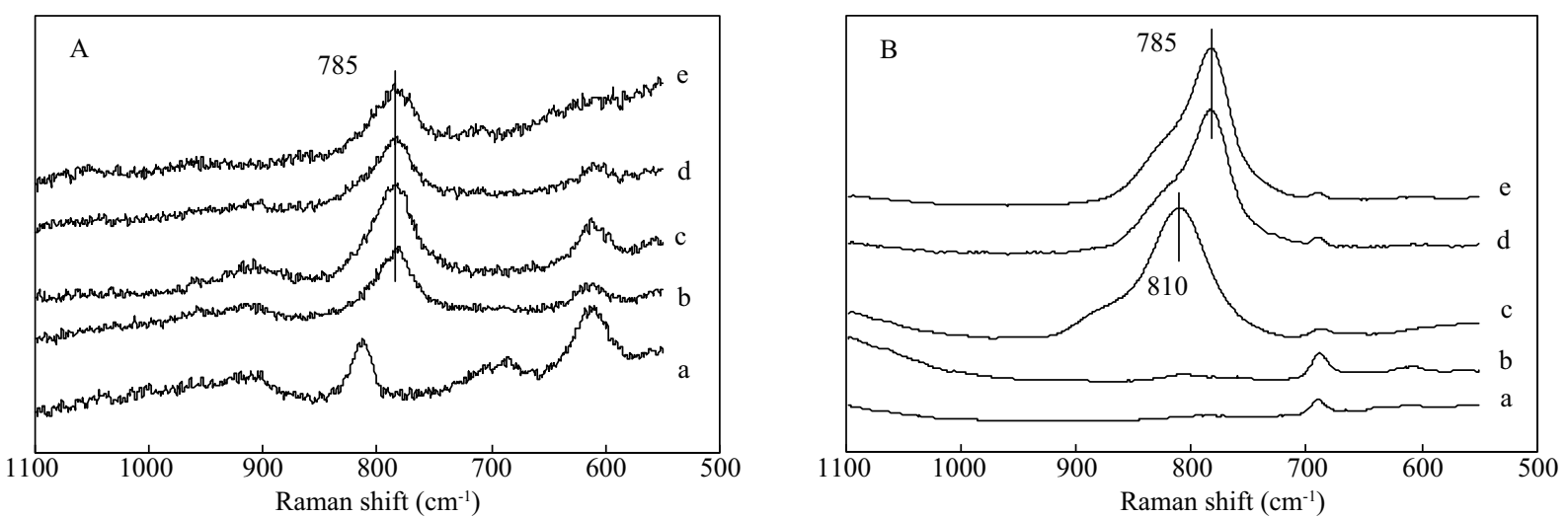

Fig. 2 (A) SERS spectra of DI water blank (line a), $1 \mathrm{mg} / \mathrm{L}$ As mixed with humic acid at $0 \mathrm{mg} / \mathrm{L}$ (line b), $1 \mathrm{mg} / \mathrm{L}$ (line c), $5 \mathrm{mg} / \mathrm{L}$ (line d), and 10 $\mathrm{mg} / \mathrm{L}$ (line e). (B) SERS spectra of DI water blank (line a), $10 \mathrm{mg} / \mathrm{L} \mathrm{HA}$ (line b), $10 \mathrm{mg} / \mathrm{L}$ As mixed with Ca at a molar ratio of 3:2 (line c), $10 \mathrm{mg} / \mathrm{L} \mathrm{As}$ mixed with $10 \mathrm{mg} / \mathrm{L} \mathrm{HA}$ (line d), and $10 \mathrm{mg} / \mathrm{L}$ As (line e). 
aqueous samples containing $1 \mathrm{mg} / \mathrm{L} \mathrm{As}(\mathrm{V})$. This peak was not exhibited as DI water dipped on silver substrate as blank sample. The peak was not shifted nor disappeared with increasing amount of HA up to $10 \mathrm{mg} / \mathrm{L}$. The lack of change in band position in the presence of HA suggests that no HA-As $(\mathrm{V})$ complex was formed under the experimental conditions. Had aqueous HA-As(V) complexes formed, the $\mathrm{As}(\mathrm{V})$ symmetry and the As-O banding energy would be changed accordingly which should result in peak shift or split (Du et al., 2014). The conclusion was further supported by the observation of peak shift from 785 $\mathrm{cm}^{-1}$ in $\mathrm{As}(\mathrm{V})$ solution to $810 \mathrm{~cm}^{-1}$ in calcium arsenate solution (Fig. 2B, lines $\mathbf{c}$ and $\mathbf{e})$. As $(\mathrm{V})$ can form aqueous complexes with calcium (Bothe and Brown, 1999) which subsequently shifted the As-O peak position. In contrast, no peak shift was observed in the mixture of $\mathrm{HA}-\mathrm{As}(\mathrm{V})$ solution at a $10 \mathrm{mg} / \mathrm{L}$ concentration level (Fig. 2B, lines d and $\mathbf{e}$ ).

There is no agreement on the formation of HA-As $(\mathrm{V})$ aqueous complexes. Generally accepted concept is that HA and $\mathrm{As}(\mathrm{V})$ can not form covalent bond because they are both anions, and indirect association of HA and $\mathrm{As}(\mathrm{V})$ through metal bridging is the primary mechanism (Redman et al., 2002; Lin et al., 2004). On the other hand, direct association of $\mathrm{HA}$ and $\mathrm{As}(\mathrm{V})$ has been reported under high HA concentrations at $1500 \mathrm{mg} / \mathrm{L}$ (Warwick et al., 2005). The existence of HA-As(V) complex has been confirmed using equilibrium dialysis method with $100 \mathrm{mg} / \mathrm{L} \mathrm{HA}$ and explained by ligand exchange with phenolate group in HA (Buschmann et al., 2006). In this study, As(V) and HA (up to $10 \mathrm{mg} / \mathrm{L}$ ) concentrations were within environmentally relevant range and no $\mathrm{HA}-\mathrm{As}(\mathrm{V})$ aqueous complexes was detected.

\subsection{Arsenic K-edge EXAFS analysis}

EXAFS spectroscopy was employed to determine the As local coordination environment in the presence of HA. The $k^{3}$ weighted As K-edge EXAFS spectra and the corresponding Fourier transformations (FT) are shown in Fig. 3. The FT of the EXAFS spectra isolates the contributions of different coordination shells, in which the peak positions correspond to the interatomic distances. However, these FT peak positions in Fig. 3A are uncorrected for phase shift, and they deviate from the true distance by $0.3-0.5 \AA$. The real parts of FT including both the magnitude and phase terms are shown in Fig. 3C. The structural parameters obtained by fitting the theoretical paths to the experimental spectra are listed in Table S2.

The first peak in the FT was the result of backscattering from the nearest neighbor As-O shell. The average As-O distance was $1.69 \AA$ with $\mathrm{CN}$ of 4 when HA concentrations increased from 0 to $200 \mathrm{mg} / \mathrm{L}$. EXAFS analysis confirmed that the geometry of $\mathrm{As}(\mathrm{V})$ was not changed by the formation of surface complexes in the presence of HA. The second shell can be fitted with $1.5 \mathrm{Fe}$ atoms at $3.27 \AA$ for

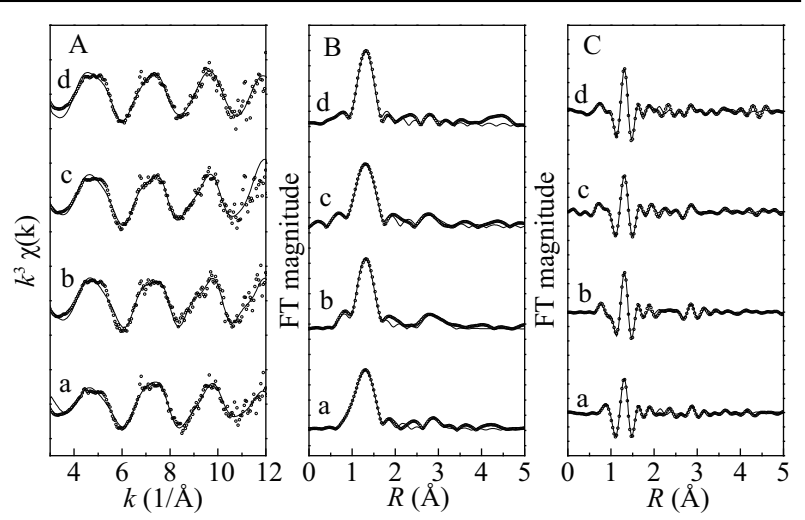

Fig. 3 Normalized $k^{3}$-weighted observed and model-calculated As K-edge EXAFS spectra (A), the corresponding magnitude of Fourier transform (B, $X$-axis not corrected for phase shifts), and real part of Fourier transform spectra (C) for HA concentrations of $0 \mathrm{mg} / \mathrm{L}$ (line a), $25 \mathrm{mg} / \mathrm{L}$ (line b), $100 \mathrm{mg} / \mathrm{L}$ (line c), and $200 \mathrm{mg} / \mathrm{L}$ (line d).

the sample without HA. The distances and $\mathrm{CN}$ of As-O and As-Fe are in good agreement with previously published data (Sherman and Randall, 2003). The As-Fe distance was in the range of 3.26-3.31 $\AA$ when HA concentration increased up to $200 \mathrm{mg} / \mathrm{L}$ which corresponds up to 20 times $\mathrm{As}(\mathrm{V})$ concentration.

The EXAFS results show that $\mathrm{As}(\mathrm{V})$ formed bidentate binuclear inner-sphere complexes on HFO surfaces in the presence of HA. No monodentate surface configuration was detected under experimental conditions which indicated that HA could not change the bidentate configuration of As(V) surface complexes.

\subsection{ATR-FITR analysis}

Figure 4 shows the ATR-FTIR spectra of DI water, As(V), $\mathrm{HA}$, and a mixture of $\mathrm{As}(\mathrm{V})$ and HA flowing through the HFO film. Spectra of DI water (Fig. 4A) and HA (Fig. 4B) feature a broad negative absorbance peak centered in 838$842 \mathrm{~cm}^{-1}$. This broad peak, increased in negative intensity with increasing time of adsorption, can be attributed to the loss of the non-H-bonded surface $\mathrm{OH}$ group upon the adsorption of proton to form positively charged surface. The band position corresponds well to those assigned to the deformation of surface $\mathrm{OH}$ groups resolved with flow cell FT-IR (Dickie and McQuillan, 2004).

Figure 4B shows vibrational bands of $\mathrm{As}(\mathrm{V})$ flowing through the HFO film. After $10 \mathrm{~min}$ of $\mathrm{As}(\mathrm{V})$ adsorption, two bands at 878 and $818 \mathrm{~cm}^{-1}$ were resolved. These bands, increased in intensity with increasing time of adsorption, should be attributed to adsorbed $\mathrm{As}(\mathrm{V})$ species. Generally, the FT-IR spectrum of an outer-sphere complex should resemble that of the aqueous species (Yang et al., 2012). In contrast, significant changes in adsorbed (Fig. 4B) and aqueous $\mathrm{As}(\mathrm{V})$ spectra suggest the formation of inner-sphere $\mathrm{As}(\mathrm{V})$ complex on HFO surface. The bands at 878 and $818 \mathrm{~cm}^{-1}$ can be assigned to stretching vibrations of uncomplexed As-O and complexed As-OFe, 

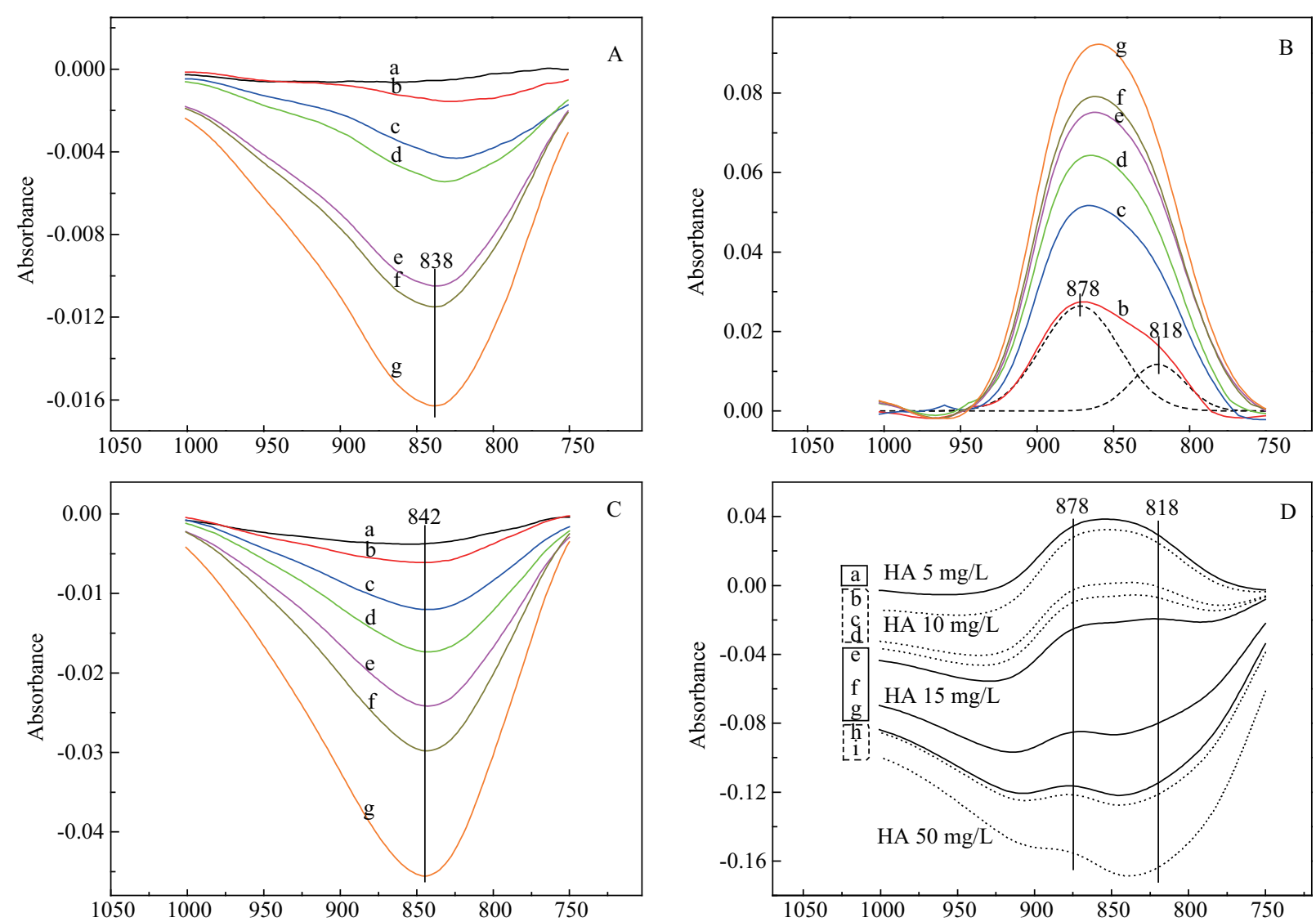

Fig. 4 ATR-FTIR spectra on HFO film at different times of adsorption at pH 7 for DI water (A), $5 \mathrm{mg} / \mathrm{L} \mathrm{As(V)} \mathrm{(B),} 5 \mathrm{mg} / \mathrm{L} \mathrm{HA}(\mathrm{C})$, and $5 \mathrm{mg} / \mathrm{L}$ As(V) with increasing amount of HA (D). Adsorption time: (line a) $5 \mathrm{~min}$, (line b) $10 \mathrm{~min}$, (line c) $20 \mathrm{~min}$, (line d) $30 \mathrm{~min}$, (line e) $40 \mathrm{~min}$, (line f) 60 min, (line g) $90 \mathrm{~min}$ in Fig. 4A-C. In Fig. 4D, $5 \mathrm{mg} / \mathrm{L} \mathrm{As}(\mathrm{V})$ and HA flow over the film for $120 \mathrm{~min}$ (line a), then the HA concentration increased to 10 $\mathrm{mg} / \mathrm{L}$ (dashed lines) for 60 (line b), 90 (line c), and 120 (line d) min; followed by $15 \mathrm{mg} / \mathrm{L} \mathrm{HA}$ for 30 (line e), 60 (line f), 90 (line g) min, and $50 \mathrm{mg} / \mathrm{L}$ HA for 60 (line h), and 90 (line i) min.

respectively (Goldberg and Johnston, 2001). The number of peaks and peak positions suggest the existence of bidentate binuclear As(V) surface complexes.

When a mixture of As(V) and HA flowing through the HFO film, the two As(V) bands at 878 and $818 \mathrm{~cm}^{-1}$ were not shifted (Fig. 4D). The invariable As(V) bands in the presence of HA implies that no HA-As(V) complexes formed even after they were concentrated on the surface of HFO. The HA effect is fairly pronounced at high HA concentrations where the As-OFe band at $818 \mathrm{~cm}^{-1}$ was hardly resolvable and the As-O peak at $878 \mathrm{~cm}^{-1}$ was rather weak. In contrast to $\mathrm{As}(\mathrm{V})$ bands, the intensity of negative HA peak was enhanced. The FT-IR results are in line with the reduced $\mathrm{As}(\mathrm{V})$ adsorption with HA addition as shown in Fig. 1. Overwhelming concentrations of HA blocked the HFO surface and limited the As(V) access. This physical mask mechanism due to HA steric effect was in agreement with a previous report (Weng et al., 2007).

\section{5 $\mathrm{As}(\mathrm{V})$ competitive adsorption behavior}

The competitive adsorption of $\mathrm{As}(\mathrm{V})$ and HA on HFO was studied at a constant ionic strength of $0.04 \mathrm{~mol} / \mathrm{L}$ as
$\mathrm{NaClO}_{4}$. The adsorption edges shown in Fig. 5 demonstrate $\mathrm{As}(\mathrm{V})$ and HA exhibit anion adsorption behaviors, which has a high adsorption percentage at low $\mathrm{pH}$ and decreases to nearly zero within a narrow $\mathrm{pH}$ range. In the presence of HA, the adsorption of $\mathrm{As}(\mathrm{V})$ was compressed as evidenced by the left shift of the adsorption edge. The curves in Fig. 5 were calculated with the CD-MUSIC model listed in Table $\mathbf{S 1}$ under spectroscopic constraints. The bidentate binuclear $\mathrm{As}(\mathrm{V})$ inner-sphere surface complexes were incorporated in the model. On the other hand, HA may occupy multiple surface sites and form both innersphere and out-sphere complexes (Vermeer et al., 1998). The possible adsorbed HA including two inner-sphere and two outer-sphere complexes were applied in the model and the corresponding reactions are listed in Table S1. The model could describe the HA and As(V) adsorption edges well.

The point of zero charge (PZC) of HFO was 7.8 (Fig. 6), in line with our previous report (Yang et al., 2012). A significant shift of PZC to lower $\mathrm{pH}$ values at 6.3 and 5.8 was observed for HA and As(V) samples, respectively. The value of $\zeta$ potential was predicted well by fitting the location of the shear plane at 2.2, 1.5, 1.2, and $1.2 \mathrm{~nm}$ 


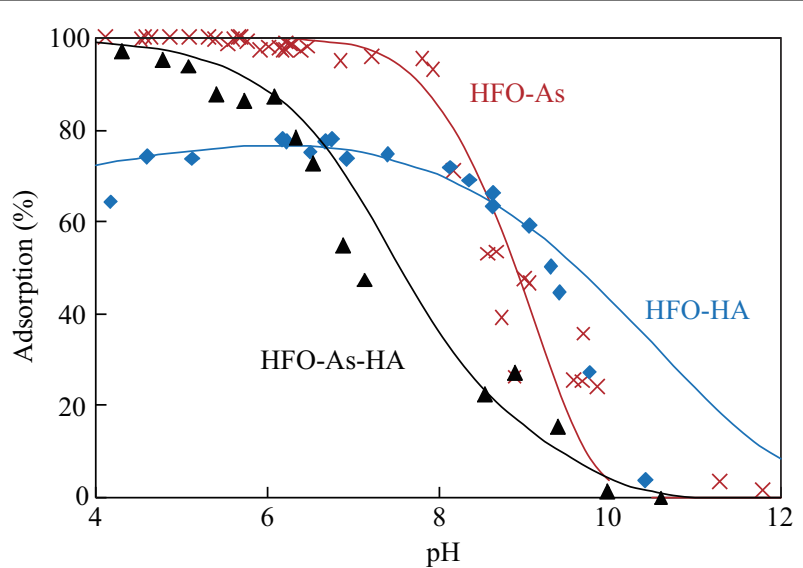

Fig. 5 Experimental adsorption edges and CD-MUSIC calculations of As(V), HA and coexistence of As(V) and HA on HFO. Total concentration: $\mathrm{As}(\mathrm{V})=0.1 \mathrm{mg} / \mathrm{L}, \mathrm{Fe}=1 \mathrm{mg} / \mathrm{L}$ in HFO-As system; $\mathrm{HA}=\mathrm{Fe}=5$ $\mathrm{mg} / \mathrm{L}$ in HFO-HA system; $\mathrm{As}(\mathrm{V})=0.1 \mathrm{mg} / \mathrm{L}, \mathrm{HA}=1.5 \mathrm{mg} / \mathrm{L}, \mathrm{Fe}=1$ $\mathrm{mg} / \mathrm{L}$ in HFO-As-HA ternary competition system. Ionic strength $=0.04$ $\mathrm{mol} / \mathrm{L} \mathrm{NaClO}_{4}$.

from the head end of the diffuse layer for HFO, HFO-HA, HFO-As, and HFO-As-HA system, respectively (Fig. 6). The derived distance was comparable with that of iron oxide (Hiemstra and vanRiemsdijk, 1996). The predicted shift of the PZC was in good agreement with experimental observations (Fig. 6). The adsorption of $\mathrm{As}(\mathrm{V})$ resulted in a greater decrease in PZC than that of HA, which may be attributed to the lower negative charge of $\mathrm{As}(\mathrm{V})$ surface complexes and the closer distance from the slipping plane to the head end of the diffuse layer. The PZC shift of the competitive system was almost identical to the As(V) system, which indicates inner-sphere As(V) surface complex

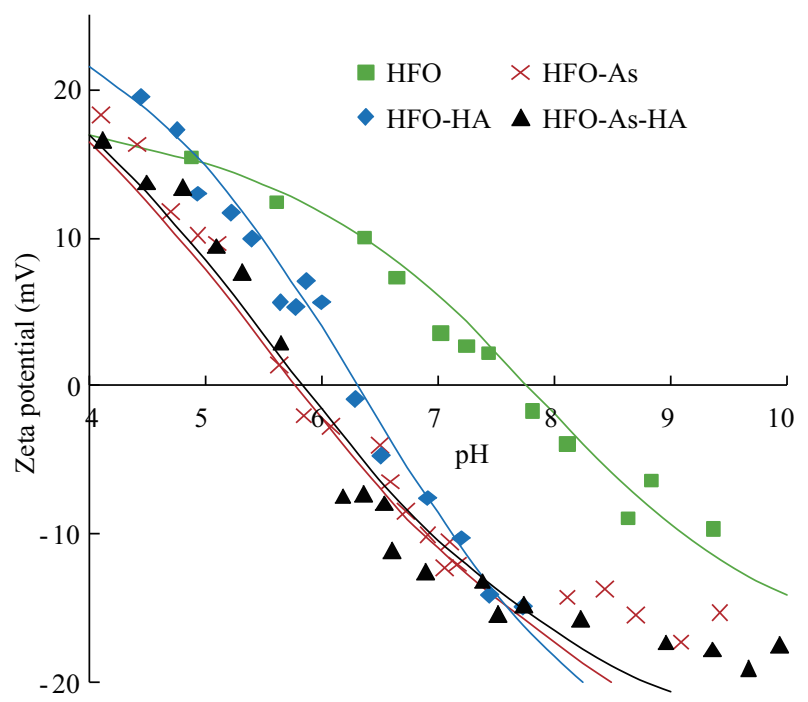

Fig. 6 Experimental and CD-MUSIC calculations of zeta potential values as a function of $\mathrm{pH}$ for HFO, HFO with humic acid, HFO with As(V), and HFO with As(V) and humic acid in $0.04 \mathrm{~mol} / \mathrm{L} \mathrm{NaClO}_{4}$ solution. The estimated distance between the shear plane and the head end of the diffuse layer is $2.2,1.5,1.2$, and $1.2 \mathrm{~nm}$, respectively, for the above four systems in the calculation. was the primary contributor to surface charge and potential over the outer-sphere HA surface complex.

\section{Conclusions}

The presence of HA has a substantial adverse effect on $\mathrm{As}(\mathrm{V})$ adsorption on HFO. The As(V) concentration (0.1 mg-As per mg-Fe) employed in batch experiments and in EXAFS studies is far below the HFO adsorption capacity (0.8 mg-As per mg-Fe) (Ford, 2002). Even at this low $\mathrm{As}(\mathrm{V})$ loading, the decrease of $\mathrm{As}(\mathrm{V})$ adsorption is statistically significant when HA concentrations are higher than 1 mg-HA per mg-Fe level. This HA adverse effect, however, is not due to the formation of aqueous HA-As(V) complexes. Competitive adsorption of $\mathrm{HA}$ and $\mathrm{As}(\mathrm{V})$ to limited surface sites is the fundamental mechanism. As(V) forms inner-sphere bidentate binuclear complexes as evidenced by an As-Fe distance of 3.26-3.31 $\AA$, and this surface configuration is not changed when HA concentration is 10 times higher than $\mathrm{As}(\mathrm{V})$.

\section{Acknowledgments}

This work was supported by the National Natural Science Foundation of China (No. 41373123, 41023005, 21321004) and Research Center for EcoEnvironmental Sciences, Chinese Academy of Sciences (No. YSW2013A01). We acknowledge the staff on beamline 14W1 at Shanghai Synchrotron Radiation Facility for their assistance with XAS data collection.

\section{Supporting information}

Supplementary data associated with this article can be found in the online version.

\section{R E F E R E N C E S}

Bothe, J.V., Brown, P.W., 1999. Arsenic immobilization by calcium arsenate formation. Environ. Sci. Technol. 33, 3806-3811.

Buschmann, J., Kappeler, A., Lindauer, U., Kistler, D., Berg, M., Sigg, L., 2006. Arsenite and arsenate binding to dissolved humic acids: Influence of $\mathrm{pH}$, type of humic acid, and aluminum. Environ. Sci. Technol. 40, 6015-6020.

Cui, J.L., Shi, J.B., Jing, C.Y., 2013. Arsenic levels and speciation from ingestion exposures to biomarkes in Shanxi, China: Implications for human health. Environ. Sci. Technol. 47, 5419-5424.

Du, J.J., Cui, J.L., Jing, C.Y., 2014. Rapid in situ identification of arsenic species using a portable $\mathrm{Fe}_{3} \mathrm{O}_{4} @ \mathrm{Ag}$ SERS senor. Chem. Commun. 50, 347-349.

Dickie, S.A., McQuillan, A.J., 2004. In-situ infrared spectroscopic studies of adsorption processes on boehmite particle films: Exchange of surface hydroxyl groups observed upon chelation by acetylacetone. Langmuir 20, 11630-11636.

Ford, R.G., 2002. Rates of hydrous ferric oxide crystallization and the influence on coprecipitated arsenate. Environ. Sci. Technol. 36, 
2459-2463.

Goldberg, S., Johnston, C.T., 2001. Mechanisms of arsenic adsorption on amorphous oxides evaluated using macroscopic measurements, vibrational spectroscopy, and surface complexation modeling. J. Colloid. Interf. Sci. 234, 204-216.

Grafe, M., Eick, M.J., Grossl, P.R., 2001. Adsorption of arsenate(V) and arsenite(III) on goethite in the presence and absence of dissolved organic carbon. Soil Sci. Soc. Amer. J. 65, 1680-1687.

Grafe, M., Eick, M.J., Grossl, P.R., Saunders, A.M., 2002. Adsorption of arsenate and arsenite on ferrihydrite in the presence and absence of dissolved organic carbon. J. Environ. Qual. 31, 1115-1123.

Gu, B.H., Schmitt, J., Chen, Z.H., Liang, L.Y., McCarthy, J.F., 1994. Adsorption and desorption of natural organic matter on iron oxide: Mechanisms and models. Environ. Sci. Technol. 28, 38-46.

Hiemstra, T., van Riemsdijk, W.H., 1996. A surface structural approach to ion adsorption: The charge distribution (CD) model. J. Colloid Interf. Sci. 179, 488-508.

Jing, C.Y., Cui, J.L., Huang, Y.Y., Li, A.G., 2012. Fabrication, characterization, and application of a composite adsorbent for simultaneous removal of arsenic and fluoride. ACS Appl. Mater. Int. 4, 714-720.

Jing, C.Y., Meng, X.G., Liu, S.Q., Baidas, S., Patraju, R., Christodoulatos, C. et al., 2005. Surface complexation of organic arsenic on nanocrystalline titanium oxide. J. Colloid Interf. Sci. 290, 14-21.

Ko, I., Davis, A.P., Kim, J.Y., Kim, K.W., 2007. Effect of contact order on the adsorption of inorganic arsenic species onto hematite in the presence of humic acid. J. Hazard. Mater. 141, 53-60.

Lin, H.T., Wang, M.C., Li, G.C., 2004. Complexation of arsenate with humic substance in water extract of compost. Chemosphere 56, 1105-1112.

Liu, G., Cai, Y., 2012. Studying arsenite-humic acid complexation using size exclusion chromatography-inductively coupled plasma mass spectrometry. J. Hazard. Mater. 262, 1223-1229.

McDonald, S., Bishop, A.G., Prenzler, P.D., Robards, K., 2004. Analytical chemistry of freshwater humic substances. Anal. Chim. Acta 527, 105-124.

Mercer, K.L., Tobiason, J.E., 2008. Removal of arsenic from high ionic strength solutions: Effects of ionic strength, $\mathrm{pH}$, and preformed versus in situ formed HFO. Environ. Sci. Technol. 42, 3797-3802.

Ravel, B., Newville, M., 2005. Athena, artemis, hephaestus: Data analysis for X-ray absorption spectroscopy using IFEFFIT. J. Synchr. Radiat. 12, 537-541.

Redman, A.D., Macalady, D.L., Ahmann, D., 2002. Natural organic matter affects arsenic speciation and sorption onto hematite. Environ. Sci. Technol. 36, 2889-2896.

Ritter, K., Aiken, G.R., Ranville, J.F., Bauer, M., Macalady, D.L., 2006. Evidence for the aquatic binding of arsenate by natural organic matter-suspended Fe(III). Environ. Sci. Technol. 40, 5380-5387.

Saito, Y., Wang, J.J., Smith, D.A., Batchelder, D.N., 2002. A simple chemical method for the preparation of silver surfaces for efficient sers. Langmuir 18, 2959-2961.

Sherman, D.M., Randall, S.R., 2003. Surface complexation of arsenie(V) to iron(III) (hydr)oxides: Structural mechanism from $a b$ initio molecular geometries and EXAFS spectroscopy. Geochim. Cosmochim. Acta 67, 4223-4230.

US EPA., 2000. Technologies and costs for removal of arsenic from drinking water, EPA report 815-r-00-028.

Vermeer, A. W.P., van, Riemsdijk, W.H., Koopal, L.K., 1998. Adsorption of humic acid to mineral particles. 1. Specific and electrostatic interactions. Langmuir 14, 2810-2819.

Wang, S., Mulligan, C.N., 2009. Effect of natural organic matter on arsenic mobilization from mine tailings. J. Hazard. Mater. 168, 721-726.

Warwick, P., Inam, E., Evans, N., 2005. Arsenic's interaction with humic acid. Environ. Chem. 2, 119-124.

Weng, L. P., Van Riemsdijk, W.H., Hiemstra, T., 2007. Adsorption of humic acids onto goethite: Effects of molar mass, $\mathrm{pH}$ and ionic strength. J. Colloid Interf. Sci. 314, 107-118.

Yang, Y.L., Yan, W., Jing, C.Y., 2012. Dynamic adsorption of catechol at the goethite/aqueous solution interface: A molecular-scale study. Langmuir 28, 14588-14597.

Yu, S.W., Du, J.J., Luo, T., Huang, Y.Y., Jing, C.Y., 2012. Evaluation of chromium bioaccessibility in chromite ore processing residue using in vitro gastrointestinal method. J. Hazard. Mater. 209-210, 250255 . 